\title{
A privát szféra architektúrája
}

A szerző az internet megjelenésével átalakuló privát szféra architektúrájának módosulásait elemzi a megfigyelhetőség és a kutathatóság közötti különbségtétel alapján. A cikk az internet térnyerésének korai szakaszában jelent meg: a szerző az architektúra-változás és a privátszféra megfelelő védelme érdekében új szemléletmód kialakítására tesz javaslatot. A privátszféra védelmére szolgáló társadalmi eszközöket két csoportra osztja: szabályozási eszközökre és technológiai megoldásokra. A szabályozási eszközökön belül megkülönbözteti a jogi szabályozást és a társadalom által felállított normákhoz kapcsolódó piaci önszabályozást.

\section{Szerzői információ:}

\section{Lawrence Lessig}

Amerikai jogász, a Stanford Egyetem jogi karának professzora és az egyetemen múködő Internet és Társadalom Központ alapítója. A Philadelphiai Egyetemen közgazdasági, a Cambridge-i Egyetemen filozófiai, a Yale Egyetemen pedig jogtudományi diplomát szerzett A Scientific American 2003-ban az ötven legnagyobb újító közé választotta. Ügyvédként részt vett az amerikai igazságügyi minisztériumnak a Microsoft elleni perében és a rendkívüli jelentôségú Eldredv. Ashcroft perben. A Wired magazin rovatvezetóje. Számos könyve jelent meg az internettel kapcsolatos jogokról és a szerzói jogról. A szellemi alkotások közkinccsé tételét szorgalmazó Creative Commons program vezetôje, az Electronic Frontier Foundation tanácsadó testületének tagja.

\section{Így hivatkozzon erre a cikkre:}

Lessig, Lawrence. „A privát szféra architektúrája”.

Információs Társadalom V, 2. szám (2005): 55-74. 
L aw rence Lessig

\section{A privát szféra architektúrája*}

Mindannyiunk életének van egy megfigyelhetô része és egy kutatható része. A megfigyelhetố rész létemnek az a szelete, amit mások látnak, észlelnek és megjegyeznek maguknak, és amire reagálhatnak is, ha a reakció az adott körülmények között megfelelő́nek túnik. Életem kutatható része pedig az, ami nyomot hagy, esetleg maga is nyomnak minôsül. Amikor végigmegyek az utcán, viselkedésem megfigyelhetô. Ha egy kis kínai falu utcáján sétálnék, viselkedésemet meglehetôs alapossággal követnék nyomon. A megfigyelés mindkét esetben átmeneti lenne csupán - az emberek megjegyeznék maguknak például azt, ha egy elefánttal, vagy nói ruhában sétálnék, de ha a sétámban semmi különleges nem lenne, ha egyszerúen beleolvadnék a tömegbe, akkor az adott pillanatban észrevennének ugyan, de nem sokkal késóbb el is feledkeznének rólam.

Életem kutatható része kevésbé átmeneti jellegú. Naplómba vetett jegyzeteim rögzítik gondolataimat. Kutathatók. A házamban található dolgok az általam birtokolt javak leltárát adják. Ezek is kutathatók. A telefonom üzenetrögzítoojén található felvételek rögzítik, ki hívott, és mit mondott. Ezek az üzenetek is kutathatók. Életemnek ezek a részei nem múlnak el olyan könnyedén, nem ugyanolyan tiszavirág-életúek, mint a csak megfigyelhetố részek, hanem a késóbbiekben feldolgozhatók, ha a technika - és a jogrend - ezt lehetôvé teszi.

Ez az esszé a privát szféráról szól. Célom az, hogy a két fent leírt, egymástól igencsak különböző jelenségen keresztül mutassam be a privát szféra fogalmát. A privát szféra, legalábbis abban az értelemben, ahogyan itt használom, e két gondolat segítségével leírható, hiszen éppen velük kel versenyre. A privát szféra ugyanis nem más, mint az, ami akkor marad, ha a társas lét egészéból kivonjuk a megfigyelt és a kutatható elemeket. Az a lét, amelyben kevesebb a megfigyelt elem, „privátabbnak” számít; az a lét, amelynek kevesebb eleme kutatható (legalábbis legálisan), ugyancsak privátabb. Így e két jelenség múködésének, architektúrájának a megértése lehetôvé teszi, hogy megértsünk valamit a privát szférának abból a részéból, ami az adott speciális körülmények között egyáltalán megvalósulhat.

A privát szférának számos ilyen architektúrája van. Közülük sokféle létezik napjainkban egymással párhuzamosan a világ különbözó részein, és vannak olyanok is, amelyek csak egy-egy adott kultúrkör történetében lelhetók fel. Mégis a fent leírt általános módszert kívánom arra használni, hogy bemutassam a privát szféra architektúráit, hi-

* Az esszé az 1998 márciusában Tajpejben tartott Taiwan Net'98 konferenciára készült. A szerzố köszönetet mond Jack és Lillian Berkmannak, a vállalati jog professzorainak a Harvard egyetem jogi karán. Az esszé egy korábbi változatához füzött, különösen értékes megjegyzéseikért köszönetet mond továbbá Tim Wunak és Ching-Yi Liu professzornak. 
szen így nyílik mód arra, hogy a különféle kontextusokban megnyilvánuló jelenségeket általában összevethessem egymással. Különösképpen pedig azért folyamodom ehhez a módszerhez, hogy megmutathassam, miért különbözik az a világ, aminek most éppen a küszöbén állunk olyan rendkívüli módon bármi mástól, amit eddig ismertünk.

Azt állítom ugyanis, hogy olyan korba lépünk be éppen, amelyben a privát szféra minden értelemben alapjaiban változik meg. Olyan korba lépünk, amelyben a megfigyelés mértéke és a kutatás lehetốségei soha nem látott méretekben megnövekednek. Dönthetünk úgy, hogy ezt a változást hagyjuk bekövetkezni. Dönthetünk azonban úgy is, hogy válaszlépésre szánjuk el magunkat. Célom az, hogy miután tisztáztam, milyen változásokra számíthatunk, vázoljam a válaszlehetôségeket, és - ha csak burkoltan is érveljek az egyik vagy a másik megoldás mellett.

\section{A megfigyelés}

Hadd magyarázzam el részletesebben, mit értek megfigyelés alatt. Mint már említettem, ez a fogalom az ember életének nyomon követett részére vonatkozik, mégpedig a mások által hétköznapi szinten, rendszeresen nyomon követett részére. Itt nem a ritkán felbukkanó kémekre gondolok, bár ha a kémkedés jobban elterjedtté válna, ez a tevékenység is nyilván a megfigyelés részét képezné. Az időról időre felbukkanó rendôrjárôr ténykedését sem tartom a megfigyelés részének. Értelmezésem szerint a megfigyelés az emberek vagy az általuk használt gépek szokásszerú, állandó és folyamatos megfigyelését jelenti, függetlenül attól, hogy a megfigyelt jelenség „,nyilvánosnak” számít-e vagy sem.

A megfigyelés ismert társadalmi jelenség. Ennek történelmileg legnyilvánvalóbb formája az, ahogyan az egyes közösségek megfigyelik tagjaikat. Az elénk táruló kép szinte közhelyszerűen ismerôs. Tudjuk, hogy a viszonylag kis közösségekben élô, szomszédjaik által ismert emberek megfigyelés alatt állnak, miközben jönnek-mennek, vásárolnak a piacon vagy beszélgetnek a kocsmában. Azt mondják, hogy minden, ami ilyen környezetben történik, mindig is köztudomásúvá vált, és ez ma is így van. Ilyen környezetben a múltban nyilván képtelenség volt kiépíteni a modern, liberális felfogásnak megfeleló privát szférát. A privát szféra nem az emberek mindennapi életében, hanem csakis a fejükben valósulhatott meg.

Ez az a kép, amely az amerikaiak szerint az Egyesült Államokat az ország alapításakor jellemezte. És ez az a kép, amely sokakat arra a következtetésre sarkall, hogy az Egyesült Államok létrejöttekor Amerikában nem létezett privát szféra. Az akkori élet a nyilvánosság elốtt élt életet jelentette. Az emberek kis településeken éltek, mindenki ismerte a szomszédait, mindenki tudott mások dolgairól. Ha az ember sokáig elmaradt otthonról, vagy ha sokat ivott, rossz társaságba keveredett, esetleg nyilvánosan durván viselkedett valakivel, vagyis ha bármilyen módon megszegte a polgári viselkedést szabályozó bonyolult normarendszert, a szabályszegés ténye figyelmet keltett, és az illetônek vállalnia kellett annak következményeit. Az ilyen társadalomban éló egyének viselkedését tehát az ott érvényes társadalmi normák szabályozták, hiszen az egyén életének nagy része ilyen értelemben nyilvánosan, vagyis - az én terminológiám szerint - megfigyelés alatt zajlott. 
Ez a leírás a korai Amerika jól ismert képét tárja elénk, de napjainkban is jellemzô az Egyesült Államok és a világ nagy részére. Számos olyan ország létezik, ahol az egyén társainak figyelố tekintete elốtt él, s ahol ez a megfigyelés jelenti a társadalmi kontrollt. A jelenség a társas lét egyik fontos aspektusára mutat rá, hiszen - véleményem szerint helyesen - hangsúlyozza azt a szerepet, amit a társadalmi normák játszhatnak a közösségek életének szabályozásában. A társadalmi normák szabályozó szerepet töltenek be, de csak akkor, ha az általuk szabályozott viselkedés megfigyelhetô. A kisvárosi életról festett kép a folyamatosan megfigyelt élet képe, és ez a megfigyelés teszi lehetôvé a szociális normák kontrollfunkcióját.

A kisváros vagy a közösség által végzett ilyen fajta megfigyelésnek ugyanakkor olyan fontos jellemzói vannak, amelyeket nem szabad figyelmen kívül hagynunk. Ezek a jellemzók a megfigyelés technikájára vonatkoznak, s ezt a fajta megfigyelést alapjaiban megkülönböztetik annak más, ismert formáitól.

Az egyik ilyen jellemzô a megfigyelési tevékenység relatíve átmeneti volta, a másik pedig a megfigyelő személye. A szomszédom esetleg emlékszik rá, hogy szombaton a piacon jártam, és még az is eszébe juthat, hogy kivel beszélgettem. Az viszont már nem valószínú, hogy fel tudja idézni, pontosan hány órakor látott, és összesen hány emberrel váltottam szót. Arra sem fog emlékezni, hogy mit vásároltam, mennyit fizettem, és vajon kis- vagy nagy címletú bankjegyekkel fizettem-e. Ismétlem: ha valami szokatlant múvelnék, vagyis ha az elefántommal érkezem a piacra, vagy egy olyan nôvel, aki nem a feleségem, akkor a kisvárosbeli viselkedésem természetesen kevésbé átmeneti jellegú megfigyelés tárgyát képezné. Akkor esetleg emlékeznének arra, hogy mit csináltam, normális esetben viszont nem. Cselekedeteimet az adott pillanatban figyelik meg, és késóbb a megfigyelésról készült „feljegyzés” a feledés homályába vész.

A megfigyelés átmeneti jellegénél is fontosabb, hogy ki végzi a megfigyelési tevékenységet. A kisvárosokban természetesen mindig lakik néhány minden lében kanál - olyan emberek, akik mások dolgába ütik az orrukat - és néhány erkölcscsôsz is, akiknek a normái szigorúbbak a többségénél. A közösségi normák efféle ốrei ugyanakkor a periférián helyezkednek el, és a jóval szúkebb belsố maghoz képest szélsôségeket képviselnek. A közösség által definiált szabadságot a morális ideáloknak ez a belső magja korlátozza. A közösség által végzett megfigyelés éppen ezt a belsô magot szolgálja ki, de korlátai a megfigyeléssel járó teher mértékét is korlátozzák. A külsố szemlélố számára ezek a normák meglehetốsen szigorúnak, sốt akár helytelennek is túnhetnek. Az adott közösségen belül azonban ezek olyan elfogadott normák, amelyeknek a közösség átlagos tagjai engedelmeskednek. A normák nem szélsőségesek, és nem is szelektívek. Nem könnyedén manipulálhatók vagy változtathatók. Belólük fakadnak a befolyásolás különféle módozatai, amelyek egymáshoz hasonló esetekben általánosságban alkalmazhatók, s az ilyen eszközök abból nyerik erejüket, hogy valamely közösség, mégpedig bizonyos normák alapján cselekvố közösség alkalmazza óket.

A fent leírt jellemzók a megfigyelés egy bizonyos architektúrájára igazak, de meg fogunk vizsgálni más jellemzókkel bíró architektúrákat is. Elóbb azonban vessünk egy pillantást a privát szféra mérlegének másik serpenyốjére, a kutathatóságra. Miért ne tennénk ezt ismét a kisváros vagy a régi Amerika példáján? 


\section{A kutathatóság}

Meghatározásom szerint a kutathatóság nemcsak annak a függvénye, hogy milyen kutatható adatok léteznek egyáltalán, hanem annak is, hogy milyen technikai eszközök állnak rendelkezésre a kutatáshoz, és ezeknek a használatát milyen jogi eszközök korlátozzák. Lássuk először a korabeli technológiát.

A technológia - egyetlen szóval kifejezve - kezdetleges volt. Nem létezett egyszerú módszer arra, hogy kihallgassanak egy beszélgetést, ami két olyan személy között zajlott le, akik biztonságosan bezárkóztak valamelyiküknek a saját lakásába. Meg lehetett volna próbálni a hallgatózást, de ez nem volt könnyú, és nem is kecsegtetett túl nagy sikerrel. Mi több, mivel az élet magántulajdonban lévő ingatlan határain belül folyt, a magánlaksértésre vonatkozó törvény védte az egyént a mások által elkövetett törvénytelen behatolástól, ideértve a rendôrséget is. A kutatható dolgok - levelek, naplók és a házban található egyéb tárgyak - között csak abban az esetben lehetett kutakodni, ha a rendốrségnek módjában állt behatolni az ember tulajdonában lévố ingatlan területére. A törvény, illetve a tulajdon architektúrájának természete megvédte a magántulajdont a rendôrség illetéktelen behatolásától. A törvény és a tulajdon architektúrája együtt a privát szféra olyan zónáját hozta létre, amelybe sem az állam, sem pedig más magánszemélyek nem tudtak egykönnyen behatolni.

Már az elsó amerikai alkotmány garantálta ezt a védelmet. Az alkotmány negyedik kiegészítése kimondja, hogy házkutatás csak indokolt esetben végezhetô, és a házkutatás elrendeléséhez alapos indok szükségeltetik. A privát szféra értékének alkotmányos megerôsítése hozzájárult ahhoz a jogi védelemhez, amit a common law már régóta biztosított. Idetartozik a magánterület-sértés és a privát szférába való egyéb behatolások elleni védelem. Ezek az elemek támogatták jogilag a privát szféra korabeli technikai vagy szerkezeti védelmét.

Így már könnyen érthetố, hogy a kutathatóság hatókörét két különbözố tényezó határozza meg. Az egyik annak a társas világnak a felépítménye, amelyet az imént vázoltam. Ezt kezdetleges kutatási technikák és az adatgyújtés viszonylag kevéssé hatékony módszerei jellemezték. Az alacsony szintú hatékonyság már önmagában is nyújtott egyfajta védelmet, megnehezítette a kutatást.

E mellett a társadalmi architektúra mellett persze ott ơrködött a jogrend is. A jog védte az egyént a kutatás ellen, korlátozta azoknak az indokoknak a számát, amelyek alapján a rendốrség kutatásba kezdhetett, $\mathrm{s}$ a privát szféra második védelmi vonalaként múkööött a fürkészố szemek behatolása ellenében.

A privát szféra az eredeti kontextusban tehát ennek az egyensúlynak a terméke volt. Az egyik oldalon ott volt a társadalmi normákat támogató struktúrák által megfigyelt lét. A másik oldalon pedig ott állt a jogrendszer és az architektúra védelme, amelyek együtt igen jelentốsen megnövelték a kutatás „költségeit”. Az életnek az utcán zajló részét megfigyelhették az ember szomszédai, de ez a megfigyelés csak csekély számú kutatható adatot eredményezett. A mégis kutatható adatokat egyrészt védelmezte a tulajdon architektúrája, vagyis az a tény, hogy a házak falai nem üvegból készültek és az emberek magukra tudták zárni az ajtót, másrészt pedig a jogrend, ideértve az alkotmányban rögzített és az íratlan jogokat egyaránt. A privát szféra egyensúlya akkoriban a megfigyelés gyakorlata és a kutatás elleni védelem között kialakult egyensúlyt jelentette. 


\section{A védelem kiterjesztése különféle kontextusokra}

Mint az eddigiekból nyilván kiderült, a privát szféra ilyen egyensúlyának nagy része mindig is az adott kor technikai lehetôségeitól függött. Ha a megfigyelés által ránk rótt terhet a megfigyelés relatíve átmeneti volta könnyebbíti, nyilvánvaló, hogy az átmenetiség kiküszöbölésére szolgáló technológiai megoldások súlyosbítják ugyanezt a terhet. Ha az otthoni privát szféra védelmére az jellemző, hogy megsértéséhez valakinek fizikailag be kell lépnie az épületbe, akkor azok a technikai eszközök, amelyek lehetôvé teszik a nem fizikai jellegú behatolást, csökkentik a privát szféra biztonságát. A technológia mindkét esetben változhat, a jognak pedig mindkét esetben szembe kell néznie azzal a kérdéssel, hogy a változásokra hogyan reagálhat úgy, hogy megórizze a privát szférát.

Az Egyesült Államokban ez a kérdés - vagyis az alkotmányos védelem reagálása a technikai eszközök változásaira - kezdetben meglehetốsen komoly nehézségekbe ütközött, s az ezek legyôzésére irányuló erófeszítések napjainkban is relevánsak. Mint az imént említettem, nemzetem alapításakor az alkotmány védelmezte az ember „személyhez, okmányokhoz és tulajdonhoz" való jogait. A szabály a következóképpen múködött. A common law védelmezte az egyént a magánlaksértéssel szemben. Ha bárki legyen az rendốr vagy magánszemély - engedély nélkül az ember birtokára lépett, a sértett jogi lépéseket tehetett az illetôvel szemben, vagyis magánlaksértés címén beperelhette azokat, akik engedélye nélkül behatoltak a birtokára.

Egyes esetekben azonban a behatoló jó okkal védekezhetett a vád ellen. Ha például rendốrtisztként éppen valamilyen búnügyben nyomozott, akkor megvédte ốt, ha késóbb az esküdtszék úgy döntött, hogy az adott körülmények között a házkutatás indokolt volt. Védett volt továbbá akkor is, ha eleve rendelkezett házkutatási engedéllyel. Az engedélyben egy bíró adott felhatalmazást a házkutatásra, s ezzel az illetô rendôrt kivonta a magánlaksértésre vonatkozó törvény hatálya alól. Így tehát a házkutatást fontolgató rendốrnek a következố választási lehetôségei voltak: ha engedély nélkül kutat, akkor késóbb - abban az esetben, ha a bíróságot nem sikerül meggyốznie arról, hogy a házkutatás indokolt volt - személyesen felelősségre vonható lesz. A másik eshetôség az volt, hogy házkutatási engedélyért folyamodik a bírósághoz, s annak birtokában mentesül a felelősségre vonás alól. Ez a rendszer tehát ugyancsak erôsen ösztönözte a nyomozót arra, hogy házkutatási engedélyt szerezzen, hacsak nem volt biztos abban, hogy késóbb a házkutatást indokoltnak ítélik.

Az alkotmányos szabályozás tehát eleve adottnak tekintette a magánlaksértéssel kapcsolatban kialakult gyakorlatot. Feltételezve, hogy az erre vonatkozó jogok érvényben maradnak, csupán két ponton léptetett hatályba minósítő feltételeket. Az elsô pontban kimondta, hogy a házkutatásnak indokoltnak kell lennie, a másodikban pedig körülhatárolta azokat a körülményeket, amelyeknek a fennállása esetén a bíró házkutatási engedélyt adhat ki. Ezt csak abban az esetben tehette meg, ha úgy látta, hogy búncselekmény elkövetésének alapos gyanúja áll fenn.

Mi történik azonban akkor, ha a házkutatás magánlaksértés nélkül is végbe mehet? Például abban az esetben, ha lehetơvé válik az elektronikus lehallgatás? Hogyan védené az alkotmány negyedik kiegészítése a privát szférát, ha az megsérthetô lenne magánterületre való behatolás nélkül? 
A kérdés először 1928-ban merült fel az Egyesült Államok Legfelsóbb Bírósága előtt, az Olmstead v. Egyesült Államok perben. Amerika ajzószerek ellen folytatott emlékezetes háborúja, a prohibíció közepette a szövetségi kormányzat elektronikus lehallgató eszközöket használt arra, hogy bizonyítékokat gyújtsön. Az állami törvények tiltják a telefonok lehallgatását, a fogyasztókkal kötött szerzódésekben pedig maguk a telefontársaságok is azt ígérték, hogy a vonalakon zajló beszélgetéseket nem hallgatja le senki. A szövetségi kormányzat ennek ellenére megkezdte a beszélgetések lehallgatását, ám az Olmstead ügy vádlottai megtámadták a módszert, mégpedig azon az alapon, hogy az megsértette az Egyesült Államok alkotmányának negyedik kiegészítését.

A Legfelsóbb Bíróság másképp gondolta. A bíróság elnöke által megfogalmazott indoklásában a testület kijelentette, hogy az alkotmány negyedik kiegészítése csak a birtokháborítás ellen véd, mivel a telefonbeszélgetések lehallgatása során nem került sor ilyen cselekményre, a negyedik kiegészítés erre az esetre nem vonatkozik. Így tehát a bíróság elfogadhatja a lehallgatás során gyújtött bizonyítékokat, és azok alapján el is ítélheti Olmsteadet a prohibíciós törvények megsértése miatt.

Brandeis bíró ugyanakkor más véleményen volt, másképp vélekedett az alkotmányról, és másképp a negyedik kiegészítés hatályáról is. Való igaz, hogy az alkotmány eredeti megfogalmazása - írta ellenvéleményében Brandeis - csak a magánlaksértés ellen nyújtott védelmet. Ám akkor, amikor az alkotmányt kidolgozták, a magánlaksértés volt az egyetlen módja annak, hogy az egyén privát szféráját megsértsék. Amikor az alkotmány annak idején hatályba lépett, a magánlaksértés tilalma a privát szféra megsértésének legjelentốsebb formája ellen nyújtott védelmet. 1928-ban azonban már más volt a helyzet. Abban az évben a mindennapi élethez tartozó kommunikáció jelentôs része már áttevő́dött a telefonvonalakra, és a magánélet is jórészt a telefonvonalak közvetítésével zajlott. Egy ilyen világban - érvelt Brandeis - a negyedik kiegészítés által biztosított védelmet úgy kell értelmezni, hogy a telefonbeszélgetések privát szféráját ugyanolyan mértékben óvja, mint az otthon biztonságát. Ahhoz, hogy az alkotmány legalább olyan mértékben védje a privát szféra biztonságát, mint amennyire az alapokmány megfogalmazásának idején tette, fontos, hogy az alkotmány ne csak a magánlaksértés ellen nyújtson védelmet.

Ha létezik bíró, aki megérdemli a világ csodálatát; ha létezik vélemény, amelynek például kell szolgálnia a jövő kiberaktivistái számára; s ha eljön az az idő, amikor a privát szféra védelmében harcba kell szállni a kibertérben is - nos, akkor Brandeis ez a bíró, s ez a vélemény és az Olmstead ügy a legfontosabb precedens. Ez a példa a lehetó legnyilvánvalóbban demonstrál egy olyan módszert, amely elsődleges fontosságúvá válhat, ha azt szeretnénk, hogy a kibertérben megốrzôdjenek az egyén személyes szabadságának értékei. Brandeis úgy dolgozott, hogy elóször meghatározta az eredeti negyedik kiegészítésben foglalt értékeket, majd leforditotta azokat oly módon, hogy érvényesek maradjanak a kibertér kontextusában is. Brandeis távolabbra tekintett az alkotmány megfogalmazóinak fejében megfordult speciális alkalmazási lehetôségeknél, és igyekezett megtalálni azt az eszmei tartalmat, amit az elődök az alkotmányban rögzíteni kívántak. Ezzel a módszerrel Brandeisnak sikerült 1928-ban is úgy olvasnia az alkotmányt, hogy megórizze annak eredeti mondanivalóját. Brandeis megtanított bennünket arra, hogy az alkotmány szerzói által vallott értékeket lefordítsuk saját nyelvünkre, s ráadásul oly módon tette ezt, hogy az alkotmányhoz való hûségen ne essék csorba. 
Bármennyire is szükségesnek tûnt már 1928-ban az alkotmány brandeisi olvasata - bármennyire is szükségesnek túnt már akkor az az olvasat, amely figyelembe vette a jogvédelem formáinak változó kontextusát - tény, hogy Brandeis nézópontját ma egyszerúen nem lehet figyelmen kívül hagyni. Ha értékelni kívánjuk a privát szféra világát abban az új korszakban, amelynek a küszöbén állunk, kénytelenek vagyunk számba venni a ma rendelkezésre álló technológiákat, vagy - ahogyan én neveztem - a privát szféra architektúráit. Az új világ beköszöntése ugyanis jóval mélyebbre hatóan és sokkal nagyobb mértékben meg fogja változtatni a privát szféra architektúráit, mint bármely eddig tapasztalt hasonló változás.

Kezdjük a változással való ismerkedést két történettel. Az elsố a megfigyelésról szól, a második a kutatásról.

Peter Lewis így indítja a New York Times hasábjain megjelent „Felejtsük el a Nagy Testvért" (Forget Big Brother) címú cikkét:

A megfigyelố kamerák követték a vonzó, fiatal szóke nốt, ahogy végigmegy a Manhattan központjában álló szálloda hallján; üvegszemükkel lesték, amint felliftezik a 23. emeletre, és a folyosó végéból diszkréten nyugtázták, ahogy bekopog a szobám ajtaján. Nem láttam ugyan a videokazettákat, de el tudom képzelni a szalagra írt digitális feliratot, amely rögzíti a találkozás pontos idejét. A felvétel jól jöhet még, ha késóbb valakinek eszébe jutna az iránt tudakozódni, mit keresett ez a hölgy, aki egyébként nem a feleségem, a szállodai szobámban egy közelmúltbeli üzleti utam során. A kamerák késóbb láttak minket, ahogy vacsorázni, majd színházba indulunk: egy középkorú, nôs texasi férfi, amint átkarol egy csinos, East Village-ben élő hölgyet, aki a lánya lehetne. ${ }^{1}$

„Ami azt illeti - teszi hozzá Lewis - a hölgy a lányom volt.”

Lewis története a megfigyelésról szól. A történet utalás a megfigyelés egyre elterjedtebb gyakorlatára, ami mára a valós térben élt életünk alkotóelemévé vált, és aminek a kibertérben még nagyobb jelentősége lesz. A kamerás megfigyeléshez vegyük még hozzá a hitelkártyás pénzfelvételról szóló bizonylatokat, a rögzített telefonbeszélgetéseket, a repülốjegyeket, a Triborough híd fizetốs kapuit, a szállodai bejelentkezéskor kitöltött papírokat, a szobapincér-szolgálat feljegyzéseit. Vegyük tehát számba mindazokat az adatokat, amelyeket mindennapjaink során összegyúijtenek rólunk, és nyilvánvalóvá válik, mi mindenre terjed ki a valós térben végzett megfigyelés.

A kibertérben persze még rosszabb lesz a helyzet, vagy éppenséggel jobb - ez nézốpont kérdése. Érzékletesen írja le a különbséget Jerry Kang cikke a Stanford Law Review címú folyóiratban:

Képzeljünk el két látogatást a bevásárlóközpontban: az egyikre a valós térben, a másikra pedig a kibertérben kerül sor. A ṿalós térben az ember elautózik a bevásárlóközpontba, ott le-föl sétál a folyosókon, bekukkant jó néhány üzletbe, és a hívogató boltok polcai között kószál. Közben vesz magának egy gombóc fagylaltot és készpénzzel

\footnotetext{
${ }^{1}$ Peter H. Lewis: Felejtsd el a Nagy Testvért. (Forget Big Brother.) The New York Times, 1998, március 12. E1.
} 
fizet érte. Betéved egy könyvesboltba és átlapoz néhány folyóiratot. Végül megáll egy ruhaüzletnél és selyemkendốt vásárol egy ismerôsének; fizetéskor hitelkártyát használ. Ebben az esetben jó néhányan lépnek kapcsolatba az emberrel, és információt gyứjtenek róla. Például amíg a bevásárlóközpontban sétál, a többi vásárló vizuális úton szerez róla értesüléseket, ha más okból nem, hát azért, hogy bele ne ütközzenek séta közben. Ez a fajta információ ugyanakkor általános jellegú (nem rögzítik például az észrevétel pontos földrajzi helyét és idejét), nem olyan formátumban „tárolják”, hogy számítógéppel fel lehetne dolgozni, nem csatolódik az ember nevéhez vagy egyéni azonosítójához, és pusztán átmeneti (az emberek rövid távú memóriájában rögzül). Az illetố, akit éppen hogy csak észrevesznek, ismeretlen marad. Egyetlen fontos kivétel van csupán: a kendôvásárlás során olyan adatokat rögzítenek, amelyek pontosak és részletesek, számítógéppel feldolgozhatók, név szerinti azonosítót tartalmaznak és potenciálisan örök életüek.

A kibertérben ezzel szemben a kivétel szabállyá válik: minden egyes interakció olyan, mint a hitelkártyás vásárlás. [...] Ebben az alternatív univerzumban az embert láthatatlan vonalkóddal jelölik meg abban a pillanatban, mihelyt elhagyja otthonát. A rendszer egyes elemeit „út-szolgáltatóknak” nevezik/262a/, akik az utcát és az ember által taposott földet biztosítják és nyomon követik, hogy pontosan hol, mikor és milyen gyorsan halad át azokon valaki. Késóbb ennek alapján kiállítják a számlát azért, hogy az ember használta az általuk biztosított infrastruktúrát. Ahogy belépünk a kiberüzlet ajtaján, a tulajdonosok láthatatlan eszközökkel mindenhová követnek bennünket, a ránk ragasztott vonalkód segítségével. A rendszer automatikusan rögzíti, milyen üzletekbe térünk be, melyik kirakatot bámuljuk meg, s mindezt milyen sorrendben és mennyi ideig tesszük. Az egyes üzletek még ennél is részletesebb adatokat gyújtenek rólunk, mihelyt beléptünk virtuális bejáratukon. A kiberkönyvesbolt például megjegyzi, mely magazinokba lapoztunk bele, rögzíti, hogy az adott magazin mely oldalait láttuk és mennyi ideig olvasgattuk azokat, sốt a viselkedésünkben felfedezhetố mintákat is elraktározza - már ha talál ilyeneket. Megjegyzi, hogy futólag belenéztünk egy egészségügyi magazinba, amely egy antidepresszáns hatású gyógynövényról közölt cikket, hét percig olvasgattunk egy hetilapot, amely egy politikus szexbotrányával foglalkozott, és villámsebesen átlapoztunk egy bulvárlapot is, amely szerint Elvis él. Persze ha vásárolunk is valamit, az üzlet és a kibertérben zajló tranzakciókat biztosító pénz- vagy hitelintézet is pontosan feljegyzi, mit vettünk esetünkben egy selyemkendôt: pirosat és drágát. ${ }^{2}$

A megfigyelés mértéke mindkét esetben növekszik, s ugyanígy mindkét esetben változik az ember mindennapi életének megfigyelés alá esố része is. S mindkét esetben igaz, hogy a változást az egyes terek architektúrájában bekövetkezett változás teszi lehetôvé. Az architektúrát arra tervezték, hogy folyamatban lévố mindennapi ügyeinkról adatokat rögzítsen. Olyan architektúrákról van szó tehát, amelyeket megfigyelésre terveztek.

Az ilyen rendszerek által összegyújtött adatok természetesen sok tekintetben hasonlítanak azokra, amelyeket talán a kisvárosi közösség is megszerez Vannak persze fontos különbségek. A megfigyelésból származó adatok ugyanis most - a közösség által

${ }^{2}$ Jerry Kang: Information Privacy In Cyberspace Transactions (Az információs privát szféra a kiber- térben folyó tranzakciókban). 50 Stanford Law Review, 1193, 1212-1220 (Stanford Law Review, 1998. április). 
összegyújtött adatokkal ellentétben - tartósan megmaradnak és visszakereshetók. Ezek az adatok nem megszerzett, majd kidobott (vagyis elfelejtett) információt jelentenek, hanem ezeket az adatokat elôször összegyújtik, majd megốrzik és kereshetôvé teszik. Nemcsak az illető közösség, hanem bárki kutathat bennük, akinek szüksége van a rögzített tényekre. Gondoljunk csak a szerte a világban tárolt, sok milliárd gigabájtnyi e-mail üzenetre. Gondolhatunk a telefontársaságok által szalagon archivált beszélgetésekre vagy a légitársaságok törzsutasairól rögzített Frequent Flyer adatbázisokra, a hitelkártyás fizetésekról kiadott bizonylatokra, a telefonkártya-adatokra, a bankautomatáknál történő készpénzkivételekre, a fizetốs autópályák kapuinál tárolt információkra. Vegyük sorra mindezt, és képet alkothatunk arról, hogy a rendszeressé vált mindennapi megfigyelés során milyen hihetetlen mennyiségú adat gyưlik össze, immár rutinszerúen, mindannyiunkról.

A megfigyelt dolgok mennyiségének növekedéséból következik a kutatható elemek számának növekedése. Minél több a megfigyelt jelenség, annál több kereshető adatot eredményez a megfigyelés, és minél nagyobb a kereshető adatok halmaza, annál több információ vár arra, hogy abban kutatni kezdjenek.

A kereshetố adatok számának növekedése mellett ugyanakkor csökkennek a kutatás költségei. A költségek csökkenése pedig - talán paradox módon - egyúttal redukálja a kutatás ellen védelmet nyújtó jogi eszközök számát is.

Az elsố változás ismerôsebben csenghet, ám a kutatás költségeit két részre kell osztanunk. A költségek egyik részét maga a keresést végző állja, a másik részét viszont az a személy, aki után kutatnak. A keresốáltal viselt költségek azok, amelyek a keresés végrehajtásával járnak együtt, ezekhez sorolható a kereséssel eltöltött idố, a kutatás elvégzésének ára stb. A kutatás tárgyává váló személy által viselt költségek elsốsorban a kutatás szubjektív költségeit jelentik, ô viseli a „kutatottsággal” együtt járó tolakodás és egyéb kellemetlenségek terheit.

A fejlett technika nagy ütemben csökkenti a költségek mindkét formáját. A valós térben a teleobjektívek, a távolsági mikrofonok, az infravörös kamerák vagy az emberi test átvilágítása mind-mind olyan eszköznek számítanak, amelyek segítségével a keresést végzố a korábbinál olcsóbban juthat eredményre. A kibertérben még drámaibb a változás: az adatok egy általánosan elfogadott protokoll szerint múködố hálózatba kerülnek, az adatok egymáshoz rendelésére szolgáló rendszerek pedig egyre kifinomultabbakká válnak. A változások mindkét esetben a keresés költségeinek radikális csökkenését hordozzák magukban, s így - bizonyos értelemben - növelik a kereshetố adatok mennyiségét.

Ugyanez a változás megy végbe azoknak a költségeknek az esetében is, amelyeket a keresés tárgyaként azonosítható személy visel. A távolról végzett testátvilágítást lehetôvé tévố eszközök, vagy azok, melyek segítségével több száz méterról lehallgatható valaki akár falakon át is, továbbá az online elérhetố adatok között végzett kutatás, amit soha senki nem vesz észre, valamint az elektronikus lehallgatás - miközben a keresố szempontjából hatékony technológiának számítanak - a kutatás tárgyára is kevesebb terhet rónak.

Ugyanakkor éppen ez a második változás teremti meg az imént említett paradoxont. Hiszen a keresés hatékonyságának növekedése nemcsak a kutatás gazdasági értelemben vett költségeit csökkenti (növelvén ezáltal a kereshetố dolgok számát), hanem 
ezzel együtt csökkenti azoknak a jogi természetú indokoknak a számát is, amelyek alapján a kutatást meg lehetne akadályozni.

Ennek okai nyilvánvalóak. A megszokott esetekben az állam kutatásra vonatkozó jogosítványait korlátozó jogi megoldások azokra a terhekre épültek, amelyeket a kutatást elszenvedố személynek kellett elviselnie. Mihelyt azonban a kutatás célpontjára háruló terhek megszúnnek, egyre kevesebb és kevesebb érv hozható fel az állam kutatáshoz való jogával szemben. Így - mivel a kutatás költségei csökkennek - megfogyatkoznak a kutathatóság szabályozását lehetôvé tevő jogi alapok is.

A fenti tétel igazolására álljon itt egy példa. Mint már említettem, az Egyesült Államok alkotmánya korlátozza az állam kutatáshoz való jogát. A kutatásnak ugyanis az alkotmány szerint „indokoltnak” kell lennie. Képzeljünk el most egy „férget”, egy számítógép- programot, amely elindul a világhálón, s annak szerkezetében lyukakat keres, amelyek lehetôvé teszik számára, hogy egy-egy komputer merevlemezére rátelepülhessen. Ezt a férget úgy tervezték, hogy semmilyen kárt ne okozzon. Nem csatolja önmagát egyetlen rendszer-programhoz vagy alkalmazási fájlhoz sem. Ehelyett egyszerúen megtelepszik a merevlemezen, és kutatni kezd rajta.

Tegyük fel, hogy ezt a férget az FBI, az Egyesült Államok szövetségi nyomozóhivatala fejlesztette ki. Tegyük fel továbbá azt is, hogy a féreg feladata egy adott fájl felkutatása, mégpedig egy jogellenesen tárolt fájlé, ami lehet például egy nemzetbiztonsági dokumentum vagy egy szoftver illegális másolata. A férget úgy tervezték, hogy a felhasználó tudta nélkül kutasson a számítógép merevlemezén, s feladatát teljes egészében a háttérben végezze. Ha megtalálja, amit keres, jelentést küld az FBI számára, felfedve a keresett fájl helyét; ha pedig nem jut eredményre, akkor egyszerúen megsemmisíti önmagát. Tegyük még hozzá, hogy a féreg nem kutathat az elöre meghatározott jogosultsági körét meghaladó mértékben.

Megsértené-e vajon egy ilyen féreg a privát szférát garantáló alkotmányos jogot? Nos, úgy gondolom, ez igen fogós kérdés. Bizonyos értelemben természetesen szó van a magánterületre való behatolásról, ám az alkotmány negyedik kiegészítése nem kötôdik többé a magántulajdon fogalmához. A negyedik kiegészítés értelmében elvégzett próba csak arra irányulhat, vajon indokolt-e a kutatás. Ebben az esetben a kutatás az ártatlanokra nem ró terhet, csak a búnösöket sújtja, s ilyen értelemben eredményesnek számít. Mivel pedig eredményes, a gyakorlatban növeli a kereshetőség, a kutathatóság hatókörét. Általános keresésnek számít, de mivel nem vonja magával az általános keresés járulékos költségeit, indokolt keresésként is felfoghatjuk csakúgy, mint a kábítószer keresésére idomított kutyák tevékenységét a repülótéren, azzal a különbséggel, hogy ebben az esetben még a kutyától sem kell félni.

A féreg csak egy példa. Ám olyan példa, amely egy általános elv felé mutat. Egyre több a megfigyelt dolog, egyre több az olcsón kutatható dolog, egyre több az olyan dolog, ami kutatható anélkül, hogy terhet róna a kutatás - mármint az eredményes kutatás - célpontjára. Más szóval, a kutatás elốtt tornyosuló gyakorlati és jogi korlátok eltûnốfélben vannak. Az ilyen korlátok eltû́nésének pedig az lesz az eredménye, hogy az ember életének egyre nagyobb része válik feltárhatóvá.

Hogyan értékeljük ezt a változást? Hogyan érthetjük meg, miból fakad? A fent leírt modell szerint elsôsorban a tér architektúrájának változásából eredeztethetjük. Forrása tehát az a változás, ami a behálózott világ architektúrájában következik be. A valós 
térben - alapesetben - nem gyúlnek adatok. A valós térben az adatgyújtés erôfeszítést kíván vagy egy közösség, vagy egy kém által tett erốfeszítést. A való világ ilyen architektúrája pedig történelmünk során azt jelentette, hogy az így gyưjiött adatok gyakorlatilag hasznavehetetlenek voltak. Az összegyứjtésük, a birtoklásuk és a felhasználásuk egyaránt túlságosan költségesnek bizonyult.

A kibertér architektúrája azonban eltér ettól, vagy mondhatnánk inkább úgy is, hogy ez az architektúra gyorsan változik. A kibertér architektúrája elképzelhető oly módon is, hogy alapvetô jellemzốjévé az adatgyújtés válik. A kibertér világa úgy is felépíthetố, hogy az adatgyújtés mindennapi gyakorlat lesz, ami láthatatlan módon, hatékonyan múködik a háttérben anélkül, hogy terhet róna a felhasználóra. Az adatokat összegyújtik; könnyedén lehet közöttük keresgélni, és a jogi védelem a keresés ellen, ami a keresés által ránk rótt terheken alapul - nos, a jogi védelem megszúnik.

Így tehát fel kell tennünk a kérdést: Hogyan reagáljunk ezekre a kibertér architektúrájában bekövetkezett technikai jellegú változásokra, amelyek általunk eddig ismeretlen világot teremtenek?

A válasz nem egyértelmú, de ha a kérdést a szabályozás kontextusába helyezzük, egyes lehetôségek nyilvánvalóvá válnak. A következő részben pontosan ez a célom: felvázolom, hogyan érthetjük meg a szabályozási környezetet és modellezni próbálom a szabályozás megértésének folyamatát. Írásom utolsó részében pedig a felállított modell alapján igyekszem majd megmagyarázni az európai és az amerikai reakciók közötti különbségeket, és megpróbálom számba venni, hogy melyik kontinensen milyen lehetôségek állnak rendelkezésünkre.

\section{Reagálás a változásokra}

Ezt a kérdést az adott kontextuson belül kell vizsgálnunk. Nem mintha az elmúlt kétszáz év-az Internet létrejöttét megelőzóen - technológiai változások nélkül telt volna el. Nem is arról van szó, hogy ezzel a kérdéssel ne kerültünk volna szembe a múltban is. Nyilvánvaló, hogy az egyén privát szférájának problematikája a modern jogtörténet alapvetô kérdései közé tartozott. Számos nemzet reagált is a változásokra, mégpedig olyan jogi természetú elóírások életbe léptetésével, amelyekkel korábbi korokban létezố védelmi módszereket igyekeztek felváltani vagy újakat teremteni.

Nem így az Egyesült Allamok. Míg a legtöbb modern demokratikus rendszer nagy jelentôségú törvényekkel védte a privát szférát, Amerika elmulasztotta ezt megtenni. Számos európai ország és sok demokratikus berendezkedésú ázsiai ország - ideértve természetesen Tajvant is - a megfigyelés és a kutatás által fenyegetett privát szférát védelmezó törvényeket hozott.

Az Egyesült Államok jóval lassabban reagált. Szülóhazám a privát szféra tekintetében inkább az „ahogy esik, úgy puffan” elvét követte. Ebben az országban nem védik általános érvényú szövetségi törvények a privát szférát, legyen szó akár az információs privát szféráról, akár az adatok védelméról. Nekünk még olyan szövetségi törvényeink sincsenek, amelyek hatékonyan garantálnák a gyógykezelésre vonatkozó személyes adatokat - ezalól az egyetlen kivételt az elvonóintézetekben kezelt páciensek védett csoportja alkotja. Ehelyett úgy alakult a dolog, hogy amikor az Egyesült Államok tör- 
vényalkotással reagált, akkor a privát szférával kapcsolatos egyedi problémákra vonatkozó törvényeket hozott. Az arra vonatkozó adatokat például, hogy az ember milyen videokazettákat vesz ki a kölcsönzókból, igen hatékonyan védelmezi a törvény, pusztán azért, mert egy bizonyos prominens amerikai személyiséget zavartak a videokölcsönzési szokásairól nyilvánosságra hozott adatok. Az Egyesült Államok törvényei szórványosak és részlegesek - mi több, hiányosak (különösen az európai adatvédelem helyzetével összevetve), és következetlenek is ahhoz, hogy valódi védelmet nyújthassanak.

Az, hogy miért is nem léteznek az Egyesült Államokban a privát szférát védelmezô törvények, összetett okokkal magyarázható. Elóször is általános kétkedés tapasztalható a területet védelmezố törvényekkel kapcsolatban; másodszor hihetetlenül erôsek a törvényileg védelmezendô privát információkat felhasználni kívánó lobbik érdekei; harmadszor pedig ott van a személyes adatok kezelóinek az az állítása, miszerint ók minden esetben tiszteletben tartják a privát szférát. Bármi legyen is azonban az oka, ne számítsunk arra, hogy az amerikai jogrendszernek ez a jellemzôje a közeljövóben drámai módon megváltozhat. Az Egyesült Államokban a privát szféra egyelóre még nem számíthat arra, hogy a törvény úgy fogja védelmezni, ahogyan Európában és egyes ázsiai országokban.

Azt jelentené ez, hogy a privát szféra védelem nélkül marad? Vagy - másképp fogalmazva - vajon csak a jog által nyújtott védelemre számíthatunk?

Gondoljunk csak arra, hogy a védelem hány fajtáját élvezi a privát szféra a valós térben - és ne csak a törvényes védelemre figyeljünk! Csupán négyet szeretnék kiemelni ezek közül. A törvény valóban a privát szféra egyik védelmezóje. A fent említett szövetségi törvényeket kiegészítik az egyes államok által hozott törvények és az alkotmány által garantált védelem is. Ezek a jogi eszközök valamennyire védik a privát szférát, az Egyesült Államokban ugyanúgy, mint Európában - itt kevésbé ugyan, mint odaát, de védik.

Az egyén privát szférájának azonban nem a törvény az egyetlen ôre. A privát szférát normák is védik. Az egyének között legalábbis a normák szabályozzák, hogy milyen kérdéseket tehet fel az ember, vagy milyen pletykákat hajlandó meghallgatni. A vállalatok szintjén pedig a normák szabályozzák azt, hogy az egyes cégek hogyan használják fel az általuk összegyújtött adatokat. Ezek a megszorítások különböznek a törvényi szabályozástól: adott esetben például nem az állam tartatja be óket, hanem az illetố közösség többi tagja által foganatosított szankciók. A szóban forgó normák ennek ellenére megszorító jellegúek, és funkciójukat tekintve a privát szférát védelmezik.

A harmadik megszorító tényezô a piac. A vállalatok jó piaci hírnevét befolyásolja az, hogy a privát szférával kapcsolatos adatokat hogyan kezelik. Egyes esetekben az is megtörténhet, hogy a cégek drágábban adnak bizonyos szolgáltatást, és cserébe azt ígérik, hogy jobban ügyelnek a privát szféra sértetlenségére.

Mindabban azonban, amiról eddig szó volt, a privát szférát védelmezô (vagy éppenséggel romboló) legfontosabb megszorítás magából az architektúrából ered. A magas kerítés biztonságos otthont teremt, a bonyolult zár a legjobban képzett betörốkön kívül mindenkit távol tart, a vastag falakon nem szúródik át a beszélgetés, az összehúzott függönyökön nem lehet átlátni. Mindezek a jellemzók valamely adott tér architektúrájára vonatkoznak, és nyilvánvaló módon kiterjesztik, illetve növelik az adott tér által biztosí- 
tott privát szférát, mint ahogy más tényezôk - például az átlátszó tükrös, üvegfalú megfigyelőszobák és börtönök, a megfigyelókamerák, az üvegezett válaszfalak vagy az ajtó nélküli irodák - csökkentik azt.

A megszorításoknak ezeket a fajtáit azért érdemes leírnunk, hogy nyilvánvalóvá tegyünk egy olyan nézốpontot, ami a privát szférával és az adatvédelemmel kapcsolatos vitákban manapság gyakran elsikkad. Tudatában kell lennünk annak, hogy bármely egyedi kontextusban ennek a négy megszorításnak a megléte vagy a hiánya határozza meg a privát szférát. Megeshet, hogy mind a négy megszorítás együttesen támogatja a privát szférát, de az is, hogy az egyik a másik ellenében múködik. Sốt, az is megtörténhet, hogy az egyik vagy a másik megszorítás uralkodóvá válik a többihez képest. Ahhoz, hogy képesek legyünk megérteni a privát szféra helyzetét valamely adott, speciális térbeli és temporális kontextusban, vagy egy bizonyos szempontból nézve, kénytelenek vagyunk a négy megszorító tényező együttesére koncentrálni.

A mindenkori környezeti feltételek figyelembevételével kell tehát megvizsgálnunk, hogy személyes adataink milyen biztonságban vannak ma az Egyesült Államokban. Mint már említettem, Amerikában a törvények viszonylag jelentéktelenek, és valószínútlen, hogy a közeljövóben nagyobb jelentôségre tennének szert. Ám a jogi eszközök mellett létező más tényezóket is figyelembe véve az igazi kérdés az, hogy a fenti megszorítások vajon képesek-e úgy kiegészíteni a törvényeket, hogy a létrejövố környezet egészében a privát szféra védelmét szolgálja?

Az alternatívák egyik csoportja a normákra épül. A Clinton-kormányzat álláspontja az volt, hogy az adatvédelemmel kapcsolatos problémákra a normák jelentik a megoldást. A kormányzat az ipartól várta el, hogy fejlessze ki a személyes adatok kezelésének szabályozására alkalmas szoftvereket. Azt akarták, hogy a fejlesztók maguk állítsák eló ezeket a programokat, és szinte kötelezố érvénnyel, állami beavatkozás nélkül maguk terjesszék el használatukat. A számítástechnikai ipar ily módon saját maga dolgozná ki szabályozásának módját, az állam pedig - annak érdekében, hogy megvédelmezze az állampolgárok privát szféráját - erre az önszabályozásra támaszkodhatna.

Ez a megoldás természetesen számos kételyt ébreszthet, s ezek között nem elhanyagolható az a feltevés, miszerint a kereskedelmi érdekek jócskán eltérhetnek a fogyasztók érdekeitól. Az ötlet ugyanakkor kétségkívül alternatívát jelent, s ennek a hatékonyságát figyelembe kell venni, amikor számba vesszük a privát szféra védelmével kapcsolatos érdekeket.

A másik alternatívát az architektúra jelenti: olyan technológiák kifejlesztése, amelyek újjáélesztik a privát szférát ott, ahol más technológiák esetleg már rombolni kezdték. A legközismertebb példa erre a titkosítás - különösen a nyilvános kulcsokon alapuló titkosítás, ami megkönnyíti, hogy az ember hatékonyan elrejthesse azokat a rá vonatkozó adatokat, amelyeket nem szeretne mások tudomására hozni.

A titkosítás ugyanakkor nem fogja tudni elrejteni a különbözó múveletek és tranzakciók során keletkezó adatokat, például az egérrel való rákattintást valamire vagy a telefonbeszélgetésekról rögzített automatikus feljegyzéseket. Mi több, arra sem lesz képes, hogy könnyedén elrejtse a mások által rólunk nyilvántartott adatokat, vagyis csak olyan mértékben tudja ezt megtenni, amennyire maguk az adatok nyilvántartói védik azokat. Ezen kívül a titkosítás furcsamód növeli a megfigyelést és a kutatást szolgáló 
technikai lehetôségek számát, hiszen olyan architektúrát támogat, amelyen belül személyi azonosítók hozhatók létre, azaz olyan architektúrákat, amelyek egyenesen megkövetelik majd a személyi azonosítók létrehozását.

Hadd magyarázzam meg ezt részletesebben. A nyilvános kulcsokra épülő titkosítási módszer megkönnyíti, hogy valaki elrejtse a mondanivalóját. Ezzel együtt azonban megkönnyíti az adatközlő személyazonosságának a megállapítását is. A titkosítás tehát egyszerre teszi lehetôvé a rejtôzködést és a személyazonosítást, hiszen ugyanaz a technikai eszköz, amely egy beszélgetés rejtjelezésére szolgál, használható a résztvevók azonosítására is. Példának okáért a digitális aláírás tanúsítja, hogy én küldtem az üzenetet, a digitális azonosító pedig tanúsítja, hogy az vagyok, akinek mondom magam. Amikor tehát a titkosításnak a privát szférára gyakorolt hatását vizsgáljuk, a technológiának éppen ezt a másik részét kell vizsgálnunk, ami lehetôvé teszi a személyazonosítást.

A személyazonosítás költségeinek csökkenésével számíthatunk arra, hogy a módszert támogató technikai megoldások száma növekedni fog. Mivel könnyebb lesz megmondani, hogy ki vagyok, számíthatok azoknak a rendszereknek a szaporodására is, amelyek megkérdezik tólem, hogy ki vagyok. A két dolog párhuzamosan múködik majd, hiszen az, hogy ki vagyok, értékes adatnak számít. Így a technológia növeli a rendszer által megismerhető adatok számát. Itt ismét olyan architektúrákról van szó, amelyek elôsegítik a megfigyelést.

Éppen ezért nem gondolom, hogy bárki - legyen bár szakértố vagy laikus - abszolút vagy akár csak viszonylagos érvénnyel kijelenthetné, hogy a titkosítási módszerek növelni fogják a privát szféra biztonságát. Azt a terminológiát használva, amellyel ezt az esszét kezdtem, a titkosítás jócskán csökkentheti a kutatható dolgok mennyiségét azáltal, hogy megvédi a rejtegetnivalót. Mindazonáltal - a személyazonosítás költségeinek csökkentése miatt - könnyen elképzelhetố, hogy egyúttal növeli a megfigyelés mértékét, s ezáltal újra csak hozzájárul a kutatható adatok számának növekedéséhez. Ez a technológia, csakúgy, mint oly sok más hasonló megoldás ezen a területen, Janus-arcú: az egyik oldalról nézve kiterjeszti a szabadságot, a másik oldalról viszont fokozza az ellenórzést.

A privát szféra biztonságának potenciális növelésére léteznek más technikai eszközök, más architektúrák is, amelyek lehetôvé tehetik, hogy a privát szféra védelmezố bástyáit visszafoglaljuk magunknak. Mielốt azonban ezekre rátérnék, vizsgáljuk meg, hogy miben segíthet a piac.

Vázlatot készítek csupán - célom e helyütt nem is lehet több. Mindössze arra nézve próbálok javaslatot tenni, hogy a piacot hogyan lehet a privát szféra védelmének érdekében megzabolázni. Természetesen nem úgy, hogy magára hagynánk, hanem magán az architektúrán eszközölt változtatás segítségével. A létrejövố mixtúra, vagyis a piac és az architektúra összeházasítása talán megoldással szolgálhat az itt vizsgált problémára.

Az ötlet lényege az, hogy az adat vagyon. Olyan eróforrás, amely mára hihetetlenül értékessé vált, és ahogy drágult, úgy próbálta az üzleti világ kiaknázni a benne rejlő lehetôségeket.

Az adatok felhasználásának költségei vannak, és ezeket a felhasználók szempontjából jelenleg externáliának számító költségeket azok viselik, akik jobban szeretnék, ha adataikat egyáltalán nem használnák fel. A megoldás lényege egy olyan rendszer létre- 
hozása, amelyben az adatok felhasználói internalizálják a költségeket. Olyan rendszerre volna szükség, amely biztosítja, hogy a cégek fizessenek az adatok használatáért.

A tulajdonjog éppen ilyen rendszer. Ha az egyének ténylegesen gyakorolhatnák az adataik ellenórzése feletti jogot, pontosabban ha az adatokat felhasználni kívánó szereplóknek ehhez elóbb jogot kellene szerezniük az adatkezeléshez, akkor üzleti tárgyalás során dólne el, hogy a személyes adatok egyáltalán felhasználhatók-e, és ha igen, akkor mire, illetve milyen mértékben. A jogok - abban az estben, ha a jogok efféle piacát ki lehetne építeni - a piaci tárgyalások eredménye szerint adódnának át.

A piac számos elónnyel jár, de a legfontosabb talán a sokféleség, a változatosság felismerése. A tulajdonjogon alapuló rendszer megadná a tulajdon birtokosának a lehetốséget arra, hogy ragaszkodjon a jogához egészen addig, amíg a vásárló ki nem fizeti az általa kívánt összeget. Ez ugyanakkor azt is jelenti, hogy különbözố személyek különbözó mértékben ragaszkodhatnak ehhez a jogukhoz. Különbözó összegeket követelhetnek. A tulajdonjogon alapuló rendszerben az eladók saját maguk dönthetnek a nekik megfeleló árról, függetlenül attól, hogy mások mit tekintenek annak.

A tulajdonjogon alapuló rendszerrel az a baj, hogy pénzbe kerül. A problémát a kifizetendő ár megtárgyalásával járó költségek jelentik. Elképzelhetetlen ugyanis, hogy az ember a világhálón való szörfölés közben minden egyes kattintáskor alkudozni kezdjen. Hogyan is lehetne tehát létrehozni ezt a tulajdonjogon alapuló rendszert?

Itt lép be a képbe az architektúra, vagyis az architektúrának az a változása, amire a korábbiakban utaltam. Tudnivaló, hogy a programozó közösség máris számos olyan javaslattal állt eló, amelyek lehetốvé tehetnék ezt a fajta alkufolyamatot.

Példa erre a World Wide Web konzorcium által kifejlesztett $P 3 P$ rendszer. A P3P a web protokollok egymással való „alkudozását” lehetôvé tévő szabvány, amelynek segítségével ezek a protokollok a privát szférával kapcsolatos kérdésekról tárgyalni tudnak. A P3P megkönnyíti, hogy a felhasználók önmaguk állítsák be, milyen feltételek mellett látogatnak el valamely honlapra, és a beállítások elvégzése után csak olyan honlapokat tekintenek meg, amelyek megfelelnek az általuk szabott feltételeknek. Maguk a szabvány szerzói így mutatják be a $P 3 P$ rendszert:

[A P $3 P$ ] olyan több irányban múködố rendszer, melynek segítségével a honlapok és látogatóik egyaránt közölhetik a személyes adatok kezelésében követett gyakorlatukat, illetve a saját preferenciáikat. Azok a honlapok, amelyeknek a gyakorlata megfelel a felhasználó igényeinek, könnyedén elérhetốk lesznek, míg más esetekben a felhasználók értesülnek az adott honlapon követett gyakorlatról, és lehetőségük nyílik arra, hogy elfogadják a kérdéses feltételeket, és ha kívánják, folytathatják a böngészést. $^{3}$

Az ötlet lényege abban áll, hogy lehetôvé teszi a számítógépek közötti kommunikációt. Az interneten már korábban megvalósult az ember és gép, illetve az ember és ember közötti kommunikáció, a $P 3 P$-hez hasonló architektúrák pedig most a gép és gép közötti párbeszédet is lehetôvé teszik. Így a tárgyalás „költségeit” maguk a gépek vise-

\footnotetext{
${ }^{3}$ Lásd http://www.w3c.org/p3p
} 
lik, s ez azt jelenti, hogy a gépekból privát szféránk sértetlensége felett ốrködő ügynökök válhatnak.

Ez a megoldás egyszerre jelenthet piaci és architekturális jellegú választ a problémára. Olyan megoldás, ami a két módszer együttes múködését vetíti eloore, és a privát szféra olyan mértékúi védelmét teremti meg, amilyenre a jog önmagában sohasem lenne képes. Ha a szabvány sikeres lesz, elégségesnek bizonyulhat arra, hogy személyes adataink egy részét megvédje, ám természetesen nem az összeset, és nem minden esetben. Bizonyos adatokat azonban - és ez talán elegendő is lehet -feltétlenül meg fog védeni, s ez a védelem minden bizonnyal kiterjedtebb lesz annál, mint amiben jelenleg részünk van.

\section{Konklúzió}

Szeretném összefoglalni, majd lezárni mondandómat.

Bemutattam egy módszert arra, hogy bármely adott kontextusban megvizsgálhassuk a privát szférát, és javasoltam, hogy tekintsük azt a megfigyelt és kutatható dolgok függvényének. Ez utóbbiak száma éppen napjainkban drámai módon növekszik - a korábbinál jóval több dolog képezi megfigyelés tárgyát és sokkal több adat lett kutatható. Erốteljes növekedés megy végbe a valós térben és a kibertérben egyaránt. Sebbel-lobbal belépünk egy olyan korszakba, amelyben sokkal több mindent meg lehet megtudni és hatékonyan összegyújteni, mint történelmünk során eddig bármikor.

Azt állítottam, hogy ezeket a változásokat az architektúrákban bekövetkezett változások idézik elố. Úgy vélem, hogy a privát szférát potenciálisan megvédeni képes megszorítások közül az architektúra által képviselt megszorítás változott a legjelentôsebb mértékben. A változás egyszerre pozitív és negatív: soha nem látott hatékonyságot tesz lehetôvé, és ugyanakkor példátlan módon növeli a megfigyelés mértékét.

Célom ebben az elóadásban egy olyan módszer bemutatása volt, melynek segítségével általánosságban megérthetố ez a változás; ugyanez a módszer lehetốvé teszi az állam lehetséges reakcióinak számbavételét is. Az egyik lehetséges reakció a törvényi szabályozás - ez Európa válasza. A jogon túl is léteznek azonban eszközök, idetartoznak a normák, a piac és az architektúra által adott válaszok. Ezek felvázolásával igyekeztem illusztrálni a modern technológia révén lehetővé vált megoldások komplexitását. A védelemnek léteznek tehát a törvényen túli formái is, ezek elterjedésében pedig sokat segíthet a kibertér.

Ez mondandóm optimista összefoglalója. Most azonban szeretnék hangot adni a jelenlegi helyzettel kapcsolatos kételyeimnek, vagy inkább nyugtalanságomnak is. Hiszen bármennyire szívesen festünk olyan jövoót, amelyben a változások helyreállítják a privát szféra korábbi állapotát, nem szabad figyelmen kívül hagynunk a már folyamatban lévớ változásokat és a privát szféra általuk elôidézett sebezhetőségét.

Azzal együtt ugyanis, hogy hiányoznak az adatok védelmét biztosító törvények, a különbözốállamok igyekeznek hasznot húzni az új architektúrák által lehetôvé tett hatékonyságból. Tajvanban például a kormányzat olyan személyes smart card, csippel ellátott kártya használatát kívánja bevezetni minden állampolgár számára, ami tartalmazza az illetố egészségbiztosítási és személyazonossági adatait, beleértve az ujjlenyomatát is. 
Ezeken a kártyákon helyet kap egy digitális aláíás, amely - amennyiben bekerül a kormányzati adatbázisba - mindenféle ügylet esetében azonosítja a tulajdonost. A tajvani kormány szándéka szerint a kártyákra a polgárok minden adata rá fog kerülni, s így tökéletes azonosító eszközök lesznek, amelyek részletesen feltárják az illetô múltját is. A hatékony személyi igazolványok jobbak, mint amelyekkel ma rendelkezünk.

A hatékonyság természetesen érték. A módszer ugyanakkor önnön felhasználásának módját ellenórző struktúrák után kiált. Olyan, a rendszerbe beépített struktúrák után, amelyek kizárják az adatok jogosulatlan felhasználását. Ahhoz, hogy a haladás hozadékát ellensúlyozzuk, a haladást ellenốrzố struktúrákat kell létrehoznunk. Ellenốrzó pontokat kell beépítenünk a felügyeleti rendszerekbe, hogy bizonyosak lehessünk benne, a felügyelet összhangban áll a hagyományainkban rejlő értékekkel.

Álláspontom szerint a fejlett technikai módszerekbe valamilyen „hatástalanító tényezốt" kell beépítenünk, egyfajta inerciát, ami megnehezíti az eszközökkel való visszaélést. Kétségkívül nehéz amellett érvelni, hogy a kibertér architektúrájába a kormányzat munkáját megnehezítố elemek kerüljenek. Nehéz dolog meggyốzóen kimutatni, hogy a kevesebb néha több is lehet.

Ez a fajta érvelés - a nehézségek ellenére - korántsem ismeretlen az alkotmányos demokráciák történetében. Valójában ezen alapul sok sikeres alkotmányos, demokratikus rendszer építménye, éppen azon, hogy az alkotmányba korlátozó struktúrákat építünk be, amelyek ellenốrzés alatt tartják és korlátozzák a kormányzat hatáskörét, és védelmet nyújtanak az állam zsarnoksága ellen. Edmund Burke* szerint például a köztársaság esszenciáját éppen az jelenti, hogy szenátus ellenơrzi a demokrácia „túlkapásait” és a végrehajtó hatalom túlkapásait is. A kormányzati struktúrában a szenátus tölti be a mérleg nyelvének szerepét. A kormányzat kormányzójaként funkcionál, vagyis olyan struktúra, ami gátat szab a demokráciában előforduló mindkét fajta szélsốségnek.

Ugyanez a gondolat segít megmagyarázni az alkotmányos demokráciákban létező alkotmányos jogok lényegét. Ezek a jogok - ahogy a kiberjogi aktivista John Perry Barlow nevezte óket - „programhibák”, vagyis akadályozó porszemek a kormányzati gépezet fogaskerekei között, olyan elemek, amelyeknek a célja a kormányzati munka hatékonyságának csökkentése, s ezáltal az emberi jogok védelme. Ezek a porszemek nemcsak az alkotmányos jogok kontextusában, hanem magán a kormányzati struktúrán belül is értékesek. Az emberek nem szeretnék, hogy tökéletesen hatékony ügyészek múködjenek, mert attól tartanak, hogy a vádeljárások zsarnoki jelleget ölthetnek. Az emberek nem kívánnak mindentól független végrehajtó hatalmat, mert attól félnek, hogy a végrehajtás önkényessé válhat. Az emberek nem kívánnak maguknak (talán még Franciaországban sem) minden hatalommal felruházott, hatékony törvényhozást. Olyan gátakat építenek be az alkotmányos demokráciába, amelyek akadályozzák a kormányzati hatalom hatékonyságát, éppen azért, hogy védjék magukat a kormányzati hatalom visszaéléseivel szemben.

Bizonyos hagyományok szellemében legalábbis így teszünk, vagy legalábbis fontos számunkra ez a kérdés. Jól értem azt a sokak által hangoztatott ellenvetést, miszerint ez a hagyomány - az alkotmányosság gondolata - mások számára idegen lehet. Megértem azt is, hogy bizonyos kultúrákból hiányzik a személyhez fúzôdő jogok ilyen felfogá-

* A XVIII. században élt brit gondolkodó. - A ford. 
sa. Belátom, hogy bizonyos kultúrákban félrevezetố lehet az egyén elsóbbségének hangoztatása a közösséggel szemben, és azt a gondolatot, miszerint a szabadság elóbbre való a biztonságnál, sokan helytelennek találhatják. Ez a megértés nemcsak onnan ered, hogy számtalanszor hallhatjuk más országokkal kapcsolatban, hanem onnan is, hogy az amerikai civilizációra vonatkoztatva is ismerốsen cseng. Emlékezzünk csak arra, hogy az Egyesült Államok nem szabadelvú országként jött létre. Az eredeti alkotmány elsốsorban a szövetségi kormányzat múködését korlátozta, az egyes államokét nem. A helyi közösségeket pedig különösen nem, hiszen ezekben a közösségekben elsôsorban a társadalmi normák együttese szabályozta az emberek viselkedését ugyanúgy, mint még ma is számos keleti kultúrában. Az elsốdleges szabályozó szerepét nem az állam, hanem a közösség töltötte be.

Így tehát megértem azt az álláspontot, miszerint a társadalmi szerveződéseknek nagyobb szerepet kell tulajdonítanunk, mint az egyénnek. Ennek ellenére állítom: még ha valaki a közösséget szeretné is az elsôdleges szabályozó szerepben látni, még ha el is vetné a személyhez füzốdố jogok eszméjét, a különbözôséghez való jogot, vagy John Stuart Mill személyes szabadságra vonatkozó elméletét, az általános tolerancia szükségességét, tehát ha el is utasítaná a személyes szabadság szélsôségesen szabadelvú felfogását, s helyette az erôs közösség, a közösségelvúség koncepcióját állítaná - nos, még ebben az esetben sem lenne oka arra, hogy elfogadja azokat a hatalom gyakorlására szolgáló technikai eszközöket, amelyeket az elôzóekben bemutattam.

Azok az ellenôrzést szolgáló architektúrák ugyanis, amelyek korunk kibervilágában feltúnnek, nem azonosak a hagyományos közösségek ellenórzési architektúráival. Már nem a közösségek figyelik meg, és a jövóben sem a közösségek fogják megfigyelni az egyének viselkedését, és nem a közösségek eróltetik rá akaratukat az egyénre. A megfigyelés feladatait az állam - a közösségtól elkülönülő, kis létszámú csoport - végzi el. Ez a különbség pedig két szempontból is rendkívüli jelentôséggel bír.

Az elsớ a méret. Az ellenốrzésnek ebben az új keletú architektúrájában már nem a „közösségé” az ellenốrzố szerep, bárhogyan is értelmezzük a közösség fogalmát. Az ellenốrzést szolgáló architektúrák haszonélvezôje a kormányzat. A kormányzat pedig olyan, mint a fegyver: nem szükségképpen rossz, ám - a fegyverhez hasonlóan - ha nem megfelelố kezekbe kerül, ugyancsak veszélyessé válhat. Éppen ezt jelenti az itt tárgyalt, jellegét tekintve tudás által szerzett hatalom: egy kis csoport kezében óriási hatalom összpontosul, s ezáltal megnövekszik annak a kockázata, hogy a kormányzat zsarnokságba fordul. A kormányzat által előírható szabályok vagy követelmények nem szükségképpen azonosak azokkal, amelyeket hasonló esetben a közösség írna eló. Nem utolsósorban azért, mert elôfordulhat, hogy a közösség nem ellenốrzi az elớrásokat. Ezek az elóírások abból merítik erejüket, hogy úgy tesznek, mintha a közösség akaratát érvényesítenék. Ehelyett azonban csak egy kis csoport érdekeit juttatják érvényre. Elhallgattatják a tiltakozókat - nem mintha a közösség mindenképpen tiltakozni akarna, hanem azért, mert a létrejött ellenôrzési architektúra a kezükbe adja a megfigyelés hatalmát.

Van azonban egy még ennél is fontosabb különbség. Ha bármit megtudunk a közösségek múködéséról, vagyis azokról a viselkedésfajtákról, amelyeket egy közösség támogat vagy fenntart, valamint a beavatkozásnak azokról a módozatairól, amelyek egy közösség végét jelenthetik, akkor azt is megtudtuk, hogy egy közösség fennmaradásá- 
nak feltétele az, hogy maga gondoskodjon az általa alkotott szabályok betartatásáról. A közösség normái csak addig maradnak életben, amíg maguk a közösség tagjai vesznek részt a normák betartatásában. Kívülról nem lehet rájuk eróltetni a normákat, márpedig a jelenlegi kontextusokban a kormányzat sokszor külső tényezóként szerepel. Ha a szabályok betartatásának jogát más - az állam vagy egyéb külsố szervezet - kapja meg, akkor a közösség elveszíti a kontroll lehetôségeit. Ha a közösség lemond az ellenốrzés gyakorlásáról, ezáltal éppen a közösséget alkotó kötelékeket veszíti el. Ugyanakkor furcsa, de fontos paradoxon, hogy csak a tökéletlenül múködó közösség tudja megórizni közösség mivoltát. A tökéletesen hatékony közösség ugyanis, ami rendelkezik a normákat feltétlenül betartató, hatékonyan múködő intézményekkel, megsemmisíti önmagát. Ha a közösség tagjai nem viselik saját szabályaik betartatásának terhét, a közösség megszúnik létezni.

Az architektúra szempontjából ez annyit tesz, hogy nemcsak az a fontos, hogy a közösség milyen normákat vagy szabályokat követ. Fontosabb ennél, hogy ki tartatja be a követendố normákat. Így tehát - még ha a megfigyelési kapacitás hihetetlen mértékú növekedése elvileg azt is jelentheti, hogy több normát lehet betartatni - igaz az is, hogy ha a betartatást nem az adott közösség végzi, a közösség nem erôsödik. A normák külső kényszerítô erókké válnak, ugyanolyan, kívülállók által hozott megszorításokká, mint amilyenekkel az Egyesült Államok alapítói szándékozták korlátozni a szövetségi kormányzat múködését.

Így tehát még egy „,hagyományos” társadalom is - jobban mondva egy igazi hagyományos társadalom, amely nem önkényes hatalmaskodás leplezésére használja fel a tradíciókat - okkal kérdôjelezheti meg a hatalom kezében lévố ellenôrzési architektúrák létjogosultságát. Legalábbis jó okkal építhet be ezekbe az architektúrákba olyan korlátokat, amelyek csökkentik az ellenórzés hatékonyságát. Ezek a korlátok nem pusztán az individualizmuson alapuló társadalom céljait szolgálják, hanem ugyanilyen fontosak azért is, hogy elkerülhetô legyen a zsarnokság, ezt a célt pedig az individualista és a közösségelvú társadalmak egyaránt magukénak vallják.

Végsố konklúzióként arra szeretném felhívni a figyelmet, hogy a privát szférával kapcsolatos kérdések megvitatása során érdemes túllépni azokon a megfontolásokon, amelyek a kibertér kontextusában nem bírnak jelentôséggel. A kibertérben nem az individualista és a közösségelvú álláspontok konfliktusa jelenti.a problémát. Itt az a fố kérdés, hogy megengedett lesz-e az adatok bármilyen jellegú helyi ellenôrzése. Az egész világgal szembeállítva minden egyes közösség individuális. Az architektúrákkal kapcsolatban pedig fel kell tennünk azt a kérdést, hogy az egyénnek módja lesz-e az interneten elérhetố adatairól dönteni.

Az internet az adatgyújtés terén nem szükségképpen követi a természet törvényeit. A lehetốségek az internet architektúrájától függenek. A kibertérról és szabályozásáról folytatott diskurzusból azonban hiányzik annak mélyebb elemzése, hogy a lehetséges architektúrák milyen széles skálán mozognak. Ki kell alakítanunk egy új szemléletmódot, ami legalább olyan kritikusan viszonyul az architektúrához, mint a joghoz. Olyan gondolkodásmódra van szükség, ami megérti mindkettốnek a múködését. Arra a kérdésre, hogy miként épüljön fel az új világ, csak akkor adhatunk helyes és végsô választ, ha megértjük, hogy az építkezésért - kritikai értelemben - mi magunk leszünk felelósek. 